Marta Błąd

\title{
O pięknie ekonomii, ethosie uczonego i misji uniwersytetu - jubileusz Profesora Jerzego Wilkina
}

\author{
About the Fineness of Economy, Scientist's Ethos \\ and University's Mission - A Jubilee of Professor Jerzy Wilkin
}

\author{
Kształtem miłości piękno jest, ityle, \\ Ile ją człowiek oglądał na świecie, \\ W ogromnym Bogu, albo w sobie-pyle, \\ Na tego Boga wystrojonym dziecię, \\ Tyle o pięknem człowiek wie i głosi.
}

C.K. Norwid, Promethidion

Omnia tempus habent - pisał przed wiekami Kohelet (Ecc. 3,1). Zaiste, wszystkie rzeczy mają swój czas. Jest czas sadzenia i czas wyrywania tego, co zasadzono, pouczał Eklezjasta. I tak oto nadszedł czas zbierania owoców pracy Profesora Jerzego Wilkina, zbierania przez niego samego, jak też smakowania tych owoców przez nas, jego wychowanków i przyjaciół. Rok 2015 wyznaczył jubileusz 45 lat pracy naukowej Profesora.

Z tej okazji odbyło się spotkanie w Alma Mater Profesora, na Uniwersytecie Warszawskim, w Sali Balowej Pałacu Tyszkiewiczów Potockich, w pełni jesiennego dnia 6 listopada 2015 roku. Na uroczystość licznie przybyli przyjaciele Profesora i jego współpracownicy. Nie zabrakło przedstawicieli władz dwóch instytucji, z którymi związał Profesor swoje życie naukowe: Uniwersytetu Warszawskiego i Instytutu Rozwoju Wsi i Rolnictwa PAN. Spotkanie zainaugurowali: Jego Magnificencja Rektor UW - profesor Marcin Pałys, dziekan Wydziału Nauk Ekonomicznych UW - profesor Jan Jakub Michałek oraz Dyrektor IRWiR PAN - doktor Mirosław Drygas.

Autorka jest pracownikiem naukowym Instytutu Rozwoju Wsi i Rolnictwa PAN, ul. Nowy Świat 72, 00-330 Warszawa (e-mail: marta.blad@wp.pl). 
Zasadniczą część jubileuszu, poprowadzoną przez profesor Dominikę Milczarek-Andrzejewską i profesora Łukasza Hardta, stanowiły dwie sesje naukowe, których tytuły: „Czy ekonomia jest piękna?” oraz „Ethos naukowca i misja uniwersytetu” nawiązywały do zagadnień z zakresu filozofii, podejmowanych w ostatnich latach przez Jubilata. Wystąpienia zaproszonych gości były prawdziwą ucztą intelektualną, dlatego poświęcę tym wykładom sporo miejsca.

Pierwsza sesja nawiązywała do słynnego już artykułu Jubilata zatytułowanego Czy ekonomia może być piękna? ${ }^{1}$ Można było się spodziewać, że na tak postawione pytanie nie zostanie udzielona jednoznaczna odpowiedź. A to głównie dlatego, że mamy trudności definicyjne z pojęciem piękna. Czymże zatem jest piękno?

Próbę zmierzenia się z tym pytaniem podjął pierwszy z dyskutantów - profesor Bogusław Fiedor. Jak stwierdził, pojmowanie piękna było zróżnicowane na przestrzeni dziejów, i to nie tylko w różnych epokach, ale w obrębie tej samej kultury. Można się o tym przekonać, biorąc do ręki książkę Umberto Eco Historia piękna. Profesor Fiedor przypomniał rozróżnienie, wprowadzone przez Fryderyka Nietzschego, na piękno apollińskie i dionizyjskie (bóg piękna, prawdy i porządku - Apollo contra bóg dzikiej natury i winnej latorośli - Dionizos). Piękno apollińskie to ład, symetria, harmonia, dionizyjskie zaś ma w sobie bolesny ładunek i pierwiastek szaleństwa.

Większość współczesnych ludzi myśli o pięknie jednak w kategoriach subiektywizmu. David Hume w Esejach z dziedziny moralności, polityki i literatury pisał: „Piękno nie jest właściwością przedmiotu samo przez się. Istnieje jedynie w umyśle, który je ogląda, a każdy umysł dostrzega inne piękno". Tak uważają niektórzy.

Piękno w sztuce, jakkolwiek by je rozumieć, to jednak coś innego niż piękno w nauce. Czymże zatem jest piękno w nauce? Profesor Fiedor zwrócił uwagę na poszukiwanie piękna ekonomii: w metodzie badawczej i sposobie opisu rzeczywistości gospodarczej, we wzorach matematycznych (matematyka jako archetyp piękna). Wydaje się, że ekonomistom bliżej do piękna apollińskiego: wszak zarówno klasycy (Adam Smith, David Ricardo), jak i ekonomiści głównego nurtu współczesnej ekonomii, nota bene nobliści, choćby Kenneth Arrow czy Robert Solow, nawiązują do kategorii równowagi jako centrum grawitacji systemu ekonomicznego, zrównoważenia zarówno na poziomie indywidualnego zachowania podmiotów, jak i w skali całej gospodarki.

Takie rozumienie oznacza uniwersalizację ekonomii jako nauki i jej „redukcję” do dyscypliny, która zajmuje się odkrywaniem harmonii i porządku gospodarczego tak, jak nauki przyrodnicze poszukują harmonii w przyrodzie. Jeśli taki porządek

1 Czy ekonomia może być piękna? Rozważania o przedmiocie i metodzie ekonomii, „Ekonomista” 2009, nr 3, s. 295-313. 
istnieje, czy zatem możemy zidentyfikować jednolity ekonomiczny mechanizm objaśniania wszelkich zachowań społecznych (por. Gary Becker)? A co z porządkiem aksjologicznym, moralnym i zakorzenieniem społecznym (Mark Granovetter) jako determinantami zachowań „czysto ekonomicznych”? - na takie dylematy wskazał profesor Fiedor. I skonkludował, że piękno można odnaleźć w złożoności i różnorodności, ale wymaga to od nauki rezygnacji z uniwersalizmu, odejścia od prostoty w opisie obserwowanej rzeczywistości w kierunku „komplikacji prostoty” zgodnie z propozycją Clifforda Geertza: „Szukajcie złożoności i porządkujcie ją". I w końcu, last but not least, wszystkie te zabiegi nie mają na celu utrzymywania piękna metody badawczej, ale poszukiwanie prawdy, bo w nauce nie tyle chodzi o piękno, ile o prawdę.

Nauka, jaką jest ekonomia, jest najmłodszą z nauk, jak zanotował w swoim opus magnum (Ludzkie działalnie) Ludwig von Mises. Zauroczony ekonomią stwierdził, że zasady ekonomii są w gruncie rzeczy zasadami bardzo prostymi i można je zawrzeć na jednej stronie. Wyzwanie to podjął Mark Skousen, pisząc artykuł Ekonomia na jednej stronie, w którym streścił, właśnie na jednej stronie, 16 podstawowych zasad ekonomii. Tę prostotę i harmonię w ekonomii przypomniał nam w swoim wykładzie profesor Witold Kwaśnicki, przywołując również Henry’ego Hazlitta i jego książkę: Ekonomia w jednej lekcji, który całość tej lekcji zawarł w jednym zdaniu: „sztuka ekonomii polega na tym, by spoglądać nie tylko na bezpośrednie, ale i na odległe skutki danego działania czy programu, by śledzić nie tylko konsekwencje, jakie dany program ma dla jednej grupy, ale jakie przynosi wszystkim". Profesor Kwaśnicki przywołał także słowa Friedricha von Hayeka, bardzo ważne dla nas, parających się ekonomią: „Ekonomista nie może twierdzić, że posiada specjalną wiedzę, która kwalifikuje go do koordynowania wysiłkami innych specjalistów. Co może twierdzić, to jedynie to, że jego zawodowe borykanie się ze wszechobecnymi sprzecznościami interesów uczyniło go bardziej wrażliwym jak cokolwiek innego na fakt, że żaden umysł nie jest w stanie posiąść całej wiedzy, która kieruje działaniami społecznymi". I jeszcze jedno stwierdzenie vonhayekowskie: „Fizyk, który jest tylko fizykiem, może być pierwszej klasy fizykiem i najbardziej wartościowym członkiem społeczeństwa, ale wybitnym ekonomistą nie może być ktoś, kto jest tylko ekonomistą. Ekonomista, który jest tylko ekonomistą, jest nie tylko skończonym nudziarzem, jest wręcz niebezpieczny".

Cytat ów był celowo dobrany przez profesora Kwaśnickiego. Choć wspomniane słowa odnoszą się do wszystkich ekonomistów, w tym przypadku chodziło o jednego - Jubilata, Profesora Jerzego Wilkina, którego wszechstronne, interdyscyplinarne zainteresowania naukowe sprawiają, że nie jest on tylko ekonomistą.

Jednakże, jak to wśród naukowców bywa, profesor Kwaśnicki nie zgadza się z niektórymi poglądami Profesora Wilkina, mianowicie z jego preferencją ekonomii 
normatywnej. Nasz dyskutant, jako zwolennik szkoły austriackiej, optował za tym, by ekonomia była wolna od sądów wartościujących. To wyznanie stało się kością (przyjacielskiej) niezgody, nie dość że z Jubilatem, to także z następnym dyskutantem, profesorem Włodzimierzem Siwińskim, który uważa ekonomię za naukę normatywną, gdyż nie tylko bada ona rzeczywistość, ale też próbuje ją zmieniać. Skoro zaś badamy rzeczywistość, którą nota bene współtworzymy i na którą wpływamy, pozytywnie lub negatywnie, nie unikniemy pytań aksjologicznych. Ekonomiści mają za zadanie rozwiązywać konkretne problemy i usprawniać funkcjonowanie społeczeństwa, jak to stwierdził N. Gregory Mankiw: „Bóg zesłał makroekonomistów nie po to, by wysuwali i testowali eleganckie teorie, lecz by rozwiązywali praktyczne problemy".

Profesor Siwiński dokonał ważnego wyjaśnienia odnośnie do pojęcia obecnie dość powszechnie używanego w stosunku do ekonomii, mianowicie, dismal science (ot, choćby ostatnia książka Daniego Rodrika: Economic Rules: the Right and Wrongs of the Dismal Sciences). Otóż pojęcie dismal economics, a więc ponurość ekonomii jako nauki, oryginalnie było użyte przez Thomasa Carlyle’a nie w kontekście teorii Malthusa i wzrostu ludności, jak to się przyjęło uważać, ale odnośnie do znoszenia niewolnictwa i uwalniania chłopów. Proces ten, jak uważał Carlyle, wieszczył upadek świata, którego naturalnym stanem jest właśnie niewolnictwo. Stwierdził, cóż to za ponura nauka, owa ekonomia, która popiera taki rozwój wydarzeń jako drogę do maksymalizacji dobrobytu. Po wyjaśnieniu tego kontekstu nazwanie ekonomii dismal science można uznać za pochwałę (sic!).

Szanowny Jubilat, który wszakże swoim artykułem Czy ekonomia może być piękna? wywołał dysputę o pięknie w ekonomii, nie uważa ekonomii za dismal science. Wręcz przeciwnie! Na zakończenie pierwszej sesji poświęconej pięknie w ekonomii wyznał, że w ekonomii jest piękno, bo nauka ta potrafi urzekać, a jeśli tak, to właśnie dlatego, że ma w sobie ładunek piękna. Co więcej, bez zafascynowania i poczucia piękna, zdaniem profesora Wilkina, nie można wytrwać w nauce! W nauce jest potrzeby wymiar artyzmu. Nawet ci, którzy wnieśli olbrzymi wkład do ekonomii, jak np. Paul Samuelson, mówili, że ekonomia jest też sztuką. „Ekonomia jest najstarszą ze sztuk i najmłodszą z nauk” (człowiek bowiem musiał posługiwać się ekonomią od początku, od kiedy zaistniał). Ponadto Samuelson stwierdził, że ekonomia łączy rygory nauk ścisłych z poezją nauk humanistycznych.

Profesor Wilkin przywołał podział dokonany przez ks. profesora Michała Hellera, iż są naukowcy artyści i naukowcy rzemieślnicy, największe zaś osiągnięcia w nauce są dziełem tych pierwszych. Trudno, by naukowiec artysta nie konfrontował swoich działań $\mathrm{z}$ wartościami, jest to nieuchronne. Jubilat stwierdził na koniec: Jeśli ktoś, kto uprawia naukę, a nie ma przed sobą trzech (klasycznych) wartości: 
Prawdy, Dobra i Piękna, to powinien zająć się czymś innym! Bez tego staje się średniej klasy rzemieślnikiem. Nic oddać, nic ująć.

Przywołany ks. profesor Heller miał okazję osobiście zaprezentować swoje poglądy, gdyż był dyskutantem w drugiej sesji poświęconej ethosowi uczonego i misji uniwersytetu. Ksiądz profesor odróżnia pojęcia uczonego i naukowca, optując za pierwszym, gdyż „uczonego” charakteryzuje pewien sposób życia i swoiste nastawienie do rzeczywistości, naukowiec zaś to po prostu ktoś, kto wyuczył się zawodu i go wykonuje.

Uczony żyje w świecie teorii, a słowo teoria to powtórzenie greckiego theoria, czyli „kontemplacja”. Oznacza to, że każdy uczony jest kontemplatykiem, a więc może, $w$ rozumieniu oryginalnym, platońskim, zbliżać się do Prawdy, właśnie dzięki wpatrywaniu się w świat idei. Owo doświadczenie „mistyczne” bycia kontemplatykiem należy jednak wiązać z dużym stopniem racjonalności i naukowej trzeźwości (w przeciwieństwie do mistyki chrześcijańskiej). Ze swoimi naukowymi problemami uczony powinien obchodzić się tak, jak każą wymagania naukowe, a swoje rozwiązania traktować samokrytycznie, z otwartością na krytykę innych. Zdaniem profesora Hellera, wysoki stopień racjonalności i krytycyzmu nie tylko nie przeszkadza kontemplacji, lecz także może ją wzmacniać, a nawet sam stać się jej przedmiotem. Pomiędzy krytycyzmem i kontemplacją nie ma przeciwieństw, lecz dopełnienie i wzajemne wzmacnianie. Kontemplacja pojęć i związków między pojęciami może dostarczyć punktów wyjścia do krytycznych analiz, a klarowność krytyki doskonale nadaje się do czerpania z niej kontemplacyjnych przyjemności. Kontemplacja ma jeszcze jeden wymiar - daje poczucie uczestniczenia w czymś, co jest poza badaczem, co go przerasta, pozwala mu na starcie się z oporem badanej materii - takie oto rozważania snuł profesor Heller, dodając, że cierpienie i ból tworzenia zawsze były nieodłączną częścią kontemplacji, jaką jest uprawianie nauki.

Uczestniczenie w procesie badawczym, choć na ogół przeżywane samotnie, nigdy nie jest procesem samotniczym. Nauka jest bowiem wielkim procesem społecznym ludzkości. W nauce żaden uczony nigdy nie pracował sam, gdyż w każdej jego myśli były obecne myśli i słowa łańcucha poprzedników, być może również i takich, o których on sam nigdy nie słyszał. Uświadomienie sobie własnego miejsca i związków $\mathrm{z}$ wielkim procesem, jakim jest Nauka, też może być ważnym elementem naukowej kontemplacji.

Uczestniczenie $\mathrm{w}$ jakimkolwiek procesie zawsze dokonuje się w czasoprzestrzeni, dla nauki takim miejscem jest uniwersytet. Profesor Heller przestrzegał, by pomimo obecnej tendencji do traktowania uniwersytetu jako przedsiębiorstwa "produkującego" absolwentów na potrzeby przemysłu i gospodarki, zachować pierwotną ideę uniwersytetu przenikniętą platońskim duchem „teorii”, czyli kontemplacji. Duch teorii musi być obecny na uniwersytecie, by nie zmienić go 
w „wytwórnię zmechanizowanych robotów”. Jesteśmy świadkami przeobrażania się uniwersytetów i ten proces jest nieunikniony. Profesor Heller podkreślił jednak, że i nauka ze swej natury jest procesem rozwojowym, co więcej, to właśnie przemiany w nauce zazwyczaj inicjują przemiany w innych dziedzinach życia. Zmian tych, dziś doznających przyspieszenia jak nigdy wcześniej, nie można hamować, ale można nimi sterować. Ważne, by we wszystkich próbach sterowania procesami przemian nie utracić z oczu tej wielkiej idei: nauki jako kontemplacji.

Zadanie to jest jak najbardziej aktualne dziś, kiedy codzienne funkcjonowanie instytucji uniwersytetu drastycznie rozmija się z ideą uniwersyteckości jako wspólnoty badaczy i studentów, wspólnoty powiązanej wspólnym celem - zgłębianiem tajemnic rzeczywistości, takie refleksje snuła kolejna dyskutantka - profesor Mirosława Marody. Jednak jednocześnie uspokajała, że rozdźwięk między ideą a jej konkretyzacją nie jest niczym nowym. Uniwersytet jako instytucja wielokrotnie przeżywał okresy wzlotów i upadków. Chętnie przywoływana w dzisiejszych dyskusjach reforma Humbolta wzięła się właśnie z kryzysu ówczesnej instytucji uniwersytetu.

Hiszpański filozof José Ortega y Gasset uważał, że podstawowym zadaniem uniwersytetu jest przechowywanie kultury, nie zaś kształcenie studentów i przekazywanie im wiedzy zawodowej. Dla Ortegi y Gasseta kultura jest zespołem idei, według których społeczeństwo organizuje swoje życie. Jego zdaniem, współczesne uniwersytety kształcące profesjonalistów i naukowców urabiają ich na kulturowych barbarzyńców. Dzieje się tak dlatego, że ci, którzy nauczają na uniwersytetach, są w większości również kulturowymi barbarzyńcami za sprawą postępującej specjalizacji. Wyspecjalizowany naukowiec jest najczęściej ignorantem we wszystkim poza swoją dziedziną. Dla Ortegi y Gasseta każdy, kto nie umie dokonywać syntez i nie potrafi kierować się swoim samodzielnie ukształtowanym czy przyjętym od autorytetu systemem wartości, jest w pewnym sensie takim barbarzyńcą.

Profesor Marody zwróciła uwagę, że przyczyną tego, iż uniwersytety zaczęły wypuszczać owych specjalistów - barbarzyńców, było już za czasów Ortegi y Gasseta (lata dwudzieste ubiegłego wieku) zaniechanie uczestnictwa w szeroko rozumianej wysokiej kulturze. Skutkiem zaś zaniku kultury w uniwersytetach było uznanie szczegółowej wiedzy uczonych za wystarczające kryterium własnej „kulturalności” i znakomitości. Powielanie takiej postawy, niestety, obserwujemy również dzisiaj. Doświadczany obecnie kryzys uniwersytetu jako instytucji skłania do przemyślenia na nowo jego zadań, misji i funkcji w życiu społecznym. Co należałoby uznać za najbardziej palący problem, przed jakim stoi uniwersytet? Otóż, cytując Eco (Wyznania młodego pisarza), można stwierdzić, że: „Znikło rozróżnienie miedzy prawdą a fałszem”. Profesor Marody uważa, że naszym podstawowym zadaniem w czasach zamętu i kryzysu uniwersytetu jest nauczanie studentów tego, co 
stanowi w jej przekonaniu istotę myślenia naukowego i naukowości, a mianowicie nauczenie ich umiejętności odróżniania prawdy od fałszu (szukania i odkrywania Prawdy), umiejętności myślenia (sic!), krytycznego podejścia do zasłyszanych opinii, a także przyjemności płynących z samodzielnego formułowania sądów oraz utrzymywania jakże trudnej równowagi miedzy dystansem a zaangażowaniem.

Przemyślenie na nowo misji uniwersytetu, jego zadań i funkcji profesor Jerzy Woźnicki, kolejny dyskutant, widzi w gotowości uniwersytetu do nadążania za zmianami, które zachodzą w świecie. Uniwersytet tych zmian nie zatrzyma, ale może i powinien być gotowy je współtworzyć. Zdaniem profesora Woźnickiego, klasyczna idea uniwersyteckości nieco odchodzi w przeszłość i nie potrzeba dążyć do jej reaktywacji, a więc do powrotu do przeszłości. Uniwersytet jest predestynowany do podążania za zmianami, zawsze był nośnikiem innowacji, ba, kiedy powstawał, sam był wielką innowacją. Nie oznacza to wszakże pełnego uznania uniwersytetów jako instytucji podążających za współczesnym światem bez żadnej kontroli. Uniwersytetu trzeba bronić, zwłaszcza przed zredukowaniem jego misji do funkcji szkoleniowej (training), którą to z powodzeniem mogą wykonywać inne instytucje szkolnictwa wyższego. Jednak aby utrzymać rangę uniwersytetu, potrzebne są odpowiednie nakłady finansowe. A te obecnie są ok. 100 razy mniejsze (na jednego uczonego) niż na uniwersytetach amerykańskich (wzorem, nie tylko finansowym, ale też pod względem organizacyjnym, są prestiżowe tzw. research universities). Mimo to, na co zwrócił uwagę profesor Woźnicki, nauka polska w rankingach światowych jest umieszczona na, wcale nie najgorszym, 20 miejscu (wyżej niż polska gospodarka). Dlatego też możemy szczycić się nauką polską, co jednak nie powinno zwalniać nas z nieustannej troski o jakość naszych uniwersytetów.

Nasz Jubilat jest niewątpliwie osobą, która taką troskę przejawia. Wyrażał ją nie tylko w swoich artykułach ${ }^{2}$, ale też osobiście na swoim Jubileuszu. Profesor Wilkin podkreślił, że uniwersytet jest strażnikiem nie tylko wiedzy, ale i wartości, od których ta wiedza zależy, przekaźnikiem nie tylko zawodowych umiejętności, ale i etycznych postaw. Uniwersytet to wyjątkowe miejsce przekazywania wiedzy i wartości poprzez dialog, szczególny kontakt nauczyciela z uczniem. Tej szczególnej relacji z Mistrzem doświadczyło wielu wychowanków Profesora zgromadzonych na uroczystości. Profesor ma bowiem rzadką umiejętność przyciągania młodych ludzi, budzenia w nich fascynacji nauką i kształtowania na następców.

2 Jak wzmacniać pozycję uniwersytetu nawet $w$ trudnych czasach, „Uniwersytet Warszawski. Pismo Uczelni” 2012, nr 1, s. 2-4; Uniwersytet $w$ sieci, w chmurze i na rynku. Co z tego wynika?, „Uniwersytet Warszawski. Pismo Uczelni” 2013, nr 2, s. 9-13; Jaka powinna być misja uniwersytetu w warunkach przełomu cywilizacyjnego?, w: Misja i służebność uniwersytetu w XXI wieku, red. J. Woźnicki, Instytut Społeczeństwa Wiedzy, Fundacja Rektorów Polskich, Warszawa 2013, s. 25-30; Czy uniwersytet może uratować swoja duszę, misję i znaczenie?, „Uniwersytet Warszawski. Pismo Uczelni” 2014, nr 2, s. 8-11. 
Gratulacji, życzliwych słów płynących od przedstawicieli rozsianych po całej Polsce ośrodków naukowych było bez liku. Profesor uhonorowany został także wyrazami uznania z zagranicy. Otrzymał, jako pierwszy ekonomista z Polski, nagrodę The Fellow Award od Europejskiego Stowarzyszenia Ekonomistów Rolnych (The European Association of Agricultural Economists - EAAE), zarówno za pierwiastek naukowy: istotny i trwały wkład w rozwój ekonomii rolnictwa, jak i, co dobrze charakteryzuje osobowość Profesora, za odegranie roli w integracji ekonomistów rolnych Europy Środkowo-Wschodniej ze środowiskiem zachodnim. Szczególnym prezentem była księga jubileuszowa zatytułowana Ekonomia jest piękna?3, będąca wyrazem uhonorowania Profesora w polskim środowisku naukowym. Złożyliśmy w tej księdze 32 teksty 38 autorów z obszarów zainteresowań naukowych Profesora, mianowicie: filozofii ekonomii, relacji między państwem, gospodarką a społeczeństwem oraz rozwoju wsi i rolnictwa. Czytając tę księgę, chyba nie ma się co dziwić, że w wielu tekstach widać wyraźnie wpływ myśli Profesora na nasze spojrzenie naukowe.

Nasz Jubilat, co podkreślali zaproszeni goście, to postać ekonomisty uniwersalnego, renesansowego, nie tylko kompetentnie wypowiadającego się $\mathrm{w}$ dyscyplinie ekonomii, ale też mającego interdyscyplinarne zainteresowania badawcze, pozwalające mu szeroko patrzeć na świat. Jest Profesor kimś, kogo można postawić jako wzór Profesora Uniwersytetu: przykład cnót zawodowych i koleżeńskich. Jubilat jest wielkiego formatu uczonym, ale nade wszystko wielkiego formatu Człowiekiem: jego skromność, życzliwość, pomocną dłoń, bezinteresowność i ciepło odczuwamy dobrze my, którzy na swej drodze Go spotkaliśmy. Dziękujemy Profesorze!

3 Ekonomia jest piękna? Księga dedykowana Profesorowi Jerzemu Wilkinowi, red. Ł. Hardt, D. Milczarek-Andrzejewska, Wydawnictwo Naukowe Scholar, Warszawa 2015. 